\title{
PELATIHAN PEMBUATAN VIRGIN COCONUT OIL (VCO) SECARA FERMENTASI DI DESA BELOTAN, BENDO, MAGETAN
}

\author{
Raras Setyo Retno ${ }^{1)}$, Pujiati $^{2)}$, Sri Utami ${ }^{3)}$ \\ FPMIPA, IKIP PGRI MADIUN \\ ${ }^{1)}$ email: rarassetyo86@gmail.com \\ ${ }^{2)}$ email: poesky86@gmail.com \\ ${ }^{3)}$ email: sriutami31@yahoo.co.id
}

\begin{abstract}
VCO(Virgin Coconut Oil) isderivedfrom the old fresh fruit ofthe oilpalm(Cocosnucifera). VCOis apurecoconutoilthat resistant to heat, light, oxygenanddegradationprocess, becauseits chemical structurecontains nodouble bonds. Other characteristics of theVCOis to have aclearcolor, softaromaanddelicious taste. VCO can be process with physical, chemicalandbiological technique. Inbiology, the process of makingthe VCOis donethroughfermentationtechniquesthatusing yeastSaccharomycescereviseae. The manybenefits andbusiness opportunitiesof VCO, makingmanypeople tostart a businessinthisfield.BelotanVillage, District BendoMagetanisone of the villagesthat have the potentialtodoand to develop the VCO business because inthevillagemanylocaloil plantsthathave not beenutilizedas well as possible. The aim ofthiscommunity serviceis(1) Introducingthe simpletechnologyto makingVCO, (2) Provideguidancetothe publicthatverymanybenefitsofVCO(3) Providea discourseon the establishment ofsmall businessesVCOandmarketing managementtothesevillagecommunities
\end{abstract}

\section{Key words : VCO, Coconut, fermentation, village communities}

\section{PENDAHULUAN}

Minyak kelapa murni atau biasa disebut VCO (Virgin Coconut Oil) yang telah terbukti bermanfaat bagi kesehatan, saat ini mulai banyak dicari orang untuk menyelesaikan permasalahan kesehatan. Selain juga didukung tren yang berkembang mengenai makanan kesehatan sekarang ini mulai mengarah kepada bahan-bahan yang berasal dari alam dan murni. VCO merupakan minyak yang berasal dari buah kelapa (Cocos nucifera) tua segar yang diolah pada suhu rendah $(<60 \mathrm{C})$ tanpa proses pemutihan dan hidrogenasi. Proses tersebut membuat minyak kelapa ini dikenal dengan sebutan minyak perawan (Virgin Coconut Oil) atau ada juga yang menyebutnya minyak dara. VCO merupakan minyak kelapa murni yang tahan terhadap panas, cahaya, oksigen dan proses degradasi, karena struktur kimianya tidak mengandung ikatan ganda. Karakteristik lain dari VCO adalah memiliki warna jernih, beraroma lembut dan rasanya gurih. Selain itu VCO mengandung asam - asam lemak jenuh yang tinggi yang menjadikannya tidak mudah tengik. Virgin Coconut Oil atau minyak kelapa murni mengandung asam lemak rantai sedang yang mudah dicerna dan dioksidasi oleh tubuh sehingga mencegah penimbunan di dalam tubuh.
Di samping itu ternyata kandungan antioksidan di dalam VCO pun sangat tinggi seperti tokoferol dan betakaroten. Antioksidan ini berfungsi untuk mencegah penuaan dini dan menjaga vitalitas tubuh (Setiaji dan Prayugo, 2006). Komponen utama VCO adalag asam lemak jenuh sekitar $90 \%$ dan asam lemak tak jenuh sekitar 10\%. Virgin coconut oil merupakan salah satu bisnis yang mampu bertahan dalam keeterpurukan ekonomi yang sekarang sedang dialami bangsa Indonesia. VCO dapat menjadi kesempatan baru untuk meningkatkan taraf hidup dan membuka lapangan kerja baru.

VCO juga cukup diminati oleh masyarakat Indonesia akhir-akhir ini, karena khasiatnya. VCO adalah minyak kelapa yang memiliki kadar air dan kadar asam lemak bebas yang rendah, berwarna bening, serta berbau harum. Selain itu, minyak ini tidak mengandung kolesterol dan asam laurat diubah menjadi monolaurin. Monolaurin merupakan suatu senyawa yang bersifat antivirus, antibakteri, dan antijamur. Monolaurin dapat merusak membran lipida (lapisan pembungkus virus) salah satunya virus HIV. Virgin coconut oil dapat menurunkan tumpukan lemak dalam tubuh, mengurangi pembentukan gumpalan-gumpalan darah, mengendalikan radikal bebas dalam sel, 
menurunkan kadar kolesterol darah dan lever, menambah cadangan antioksidan dalam sel, dan menurunkan resiko terjadinya penyakit jantung dan kanker. Oleh karena itu beberapa industri farmasi, kosmetika, dan susu formula menggunakan minyak ini sebagai bahan baku. Banyaknya manfaat serta peluang usaha VCO, menjadikan banyak masyarakat untuk memulai usaha dalam bidang ini.

Desa Belotan, Kecamatan Bendo Kabupaten Magetan merupakan salah satu desa yang berpotensi untuk melakukan usaha VCO hal ini dikarenakan di desa tersebut banyak tanaman kelapa yang belum dimanfaatkan dengan sebaik-baiknya hanya saja masyarakat desa tersebut kelapa yang dihasilkan dijual dalam bentuk mentah. Dengan adanya pengabdian masyarakat seperti ini diharapkan mampu membantu masyarakat Desa Belotan, Kecamatan Bendo Kabupaten Magetan bisa meningkatkan nilai ekonomi dari kelapa dan bisa meningkatkan pendapatan masyarakat desa. Meskipun VCO ini sudah banyak dibuat dan diteliti akan tetapi aplikasi dimsayarakat masih kurang dan banyak yang belum mengetahui manfaat dari VCO tersebut.

Tujuan dari pengabdian masyarakat ini adalah : 1. memperkenalkan cara pembuatan VCO sederhana yang kaya akan manfaat, 2 . memberikan pengarahan terhadap masyarakat bahwa sangat banyak manfaat dari VCO ini, 3 . memberikan wacana tentang pendirian usaha kecil VCO serta manajemen pemasaran terhadap masyarakat Desa.

Sasaran dari program ini adalah masyarakat Desa Belotan, Kecamatan Bendo Kabupaten Magetan yang sebagian masyarakat desa mempunyai tanaman kelapa yang belum dimanfaatkan secara optimal. Selain itu masyarakat desa tersebut memiliki mata pencaharian sebagai petani dan ibu rumah tangga. Kelapa yang dihasilkan di desa tersebut masih rendah dan harga jualnya juga rendah. Harga yang rendah mengakibatkan warga tidak melakukan perawatan khusus terhadap tanaman kelapa sehinga berpengaruh terhadap produktivitas tanaman, walaupun tanaman kelapa memiliki toleransi sangat tinggi terhadap lingkungan hidupnya.

Selain menghasilkan VCO, hasil samping dan limbah produksi VCO bisa dimanfaatkan juga sebagai peluang bisnis lain seperti: 1) Sabut kelapa dibuat keset atau bahan baku jok mobil, 2) Tempurung kelapa bisa diolah menjadi peralatan rumah tangga dan bahan bakar arang, 3) Air kelapa diolah menjadi nata de coco, 4) Ampas perasan santan sebagai bahan isian kayu lapis, 5) Santan menjadi VCO, 6) Lapisan minyak di bawah VCO digunakan sebagai minyak goreng. Untuk itu dengan adanya pengabdian masyarakat seperti ini diharapkan memberikan pengenalan produk yang memilki nilai jual lebih tinggi dengan mengolah produk kelapa menjadi VCO (Virgin Coconut Oil). VCO yang akan diperkenalkan memberikan kontribusi terhadap masyarakat desa untuk memberikan peluang baru untuk membuka usaha pembuatan VCO. Selain itu terciptanya lapangan kerja baru yang mampu menampung tenaga kerja yang terampil dan juga memberikan pengembangan ketrampilan bagi dosen maupun mahasiswa untuk melaksanakan penelitian dan pengabdian masyarakat.

Target yang ingin dicapai yaitu : 1) Mengajak masyarakat Desa Belotan, Kecamatan Bendo Kabupaten Magetan untuk memanfaatkan kelapa menjadi produk olahan berupa $V C O$ yang mempunyai manfaat bagi kesehatan dan memilki nilai jual yang tinggi, 2) Adanya produk VCO (Virgin Coconut oil) tersebut diharapkan dapat meningkatkan pendapatan bagi masyarakat Desa Belotan, Kecamatan Bendo Kabupaten Magetan, 3) Masyarakat desa Belotan mempunyai satu inovasi produk olahan dari tanaman kelapa, 4) Untuk memberikan lapangan kerja baru sebagai usaha dalam pembuatan VCO untuk mendapatkan penghasilan, 5) Memberikan gambaran terhadap manfaat VCO untuk kesehatan bagi mereka yang ketergantungan terhadap obat-obat kimia, 6) Memberikan gambaran tentang mengelola usaha mulai dari produksi, pengelolaan serta pemasaran, 7) Memberikan pengalaman bagi dosen dan mahasiswa untuk terjun langsung ke masyarakat untuk memberikan penyuluahan.

\section{METODE PELAKSANAAN PROGRAM}

Sebanyak 4-6 butir kelapa diambil dagingnya kemudian diparut. Hasil parutan ditimbang sebanyak $1 \mathrm{~kg}$, kemudian membuat santan dari kelapa yang sudah di parut tersebut dan menyaringnya. Santan kelapa yang sudah jadi kemudian di endapkan selama kurang lebih 3 jam agar terjadi pemisahan antara air dan krim santannya. Setelah terjadi pemisahan maka fase air dipisahkan dengan fase krim nya, fase air dibuang menggunakan selang kecil sehingga yang tertinggal hanya fase krim saja. Krim santan yang tertinggal kemudian dilakukan pengadukan menggunakan mixer dengan kecepatan sedang selama \pm 10 menit. Krim 
santan yang sudah di aduk kemudian ditambahkan ragi \pm 2 sendok makan dan diaduk sebentar setelah itu krim yang sudah diberikan ragi didiamkan kembali selama \pm 12 jam untuk memperoleh fase minyak (VCO) yang diinginkan. 4 butir kelapa biasanya akan menghasilkan $\pm 500 \mathrm{ml}$ Virgin Coconut Oil (VCO).

\section{HASIL DAN PEMBAHASAN}

Pelatihan dan sosialisai pembuatan VCO secara fermentasi dilaksanakan pada hari Minggu tanggal 4 Mei 2014 di balai desa Belotan Kecamatan Bendo Kabupaten Magetan. Sasaran dan pelatiahn ini adalah ibu-ibu PKK desa Belotan. Pelatihan dan sosialisasi ini berjalan dengan baik dan disambut dengan baik pula oleh warga desa Belotan. Hal ini dibuktikan dengan adanya antusiame masyarakat terutama ibu-ibu PKK yang hadir dalam acara sosialisai tersebut selain itu juga dihadiri oleh perangkat desa Belotan. Sosialisasi dan Pelatihan ini dimulai dengan sambutan oleh kepala desa Belotan, kemudian pemberian materi tentang cara pembuatan VCO serta manfaatnya, praktek pembuatan VCO secara fermentasi oleh ibu-ibu PKK dan dibantu oleh tim pengabdian masyarakat IKIP PGRI Madiun

Pada awal kegiatan, ada sebagian masyarakat belum mengetahui tentang VCO hasil fermentasi alami dengan menggunakan air kelapa sebagai stater, baik itu dari warna, aroma, kekentalan, karena itu diberikan penyuluhan dan praktek langsung ke masyarakat. Proses pembuatan VCO sampai proses pemisahanair dari krem santan selesai dalam satu hari kemudian disimpan/diinkubasi semalam dan dilanjutkan besoknya sehingga terbentuk tiga lapisan pada krem santan (minyak, blondo dan air), dilanjutkan dengan proses penyaringan minyak (lapisan paling atas) dengan menggunakan kertas saring. Penyaringan diulang-ulang sehingga minyak yang diperoleh putih bening dan bersih.

Secara fisik, VCO yang dihasilkan dari hasil sosialisasi dan pelatihan bagus berwarna putih bening seperti air dan jernih. Selain itu beraroma harum dan rasa bisa diterima serta tidak tengik. Tengik terjadi akibat proses oksidasi karena tingginya kadar air dalam VCO, semakin tinggi kadar air maka VCO semakin cepat tengik. Di samping itu, protein yang masih tersisa juga bisa memicu ketengikan bila melebihi ambang batas, $0,5 \%$. Di dasar botol VCO kadang terdapat butiran kecil, halus dan putih yaitu protein yang mengendap akibat penyaringan tak sempurna. Protein merupakan sarana mikroba untuk tumbuh sehingga menyebabkan ketengikan.

Berdasarkan hasil dari sosialisasi dan pelatiahan pembuatan VCO, antusiasme ibu-ibu PKK ditunjukkan dengan banyaknya minat untuk membuat VCO tersebut karena sangat mudah untuk membuatnya. Sampel yang dibawa oleh tim juga habis karena banyaknya minat yang ingin mencicipi VCO tersebut. Selain itu banyaknya pertanyaan yang mengarah kepada pemateri tentang VCO. Berdasarkan hasil analisis situasi yang terjadi di lapangan hampir semua peserta antusias terhadap pembuatan VCO secara fermentasi bisa dijadikan peluang bisnis. Harga VCO dipasaran bisa mencapai Rp. $55.000,00 /$ botol ukuran $250 \mathrm{ml}$. Dari harga tersebut bisa dijadikan peluang bisnis yang menjanjikan mengingat bahwa alat dan bahan yang digunakan dalam pembuatan VCO mudah untuk diperoleh dan harganya relatif murah. Selain itu kami tim pengabdian masyarakat juga membuat selebaran pembuatan VCO yang disertai alat dan bahan untuk memudahkan dalam membuat VCO serta memberikan kesempatan membuka peluang usaha pembuatan VCO.

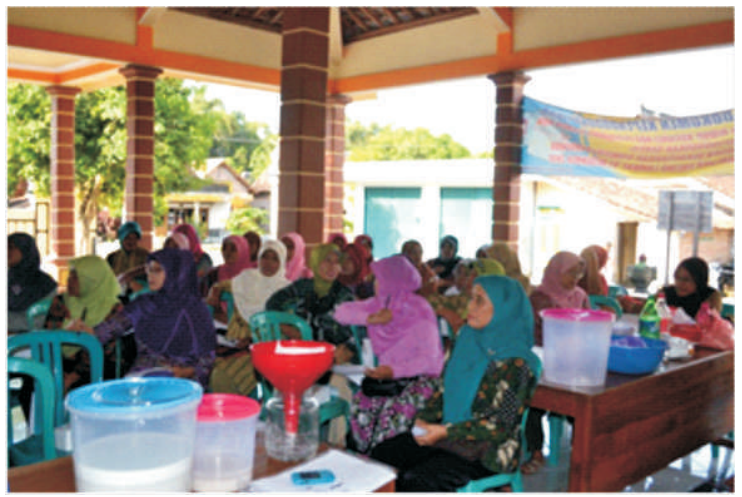

Gambar 1. Antusiasme warga

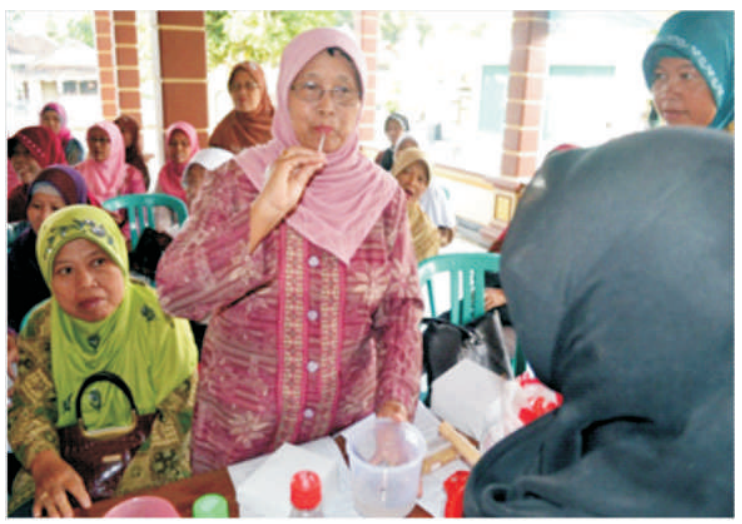

Gambar 2. Uji organoleptik oleh salah satu warga 